\title{
Effect of Global Postural Reeducation on cardiovascular system of healthy subjects
}

\author{
Efeito da Reeducação Postural Global sobre o sistema \\ cardiovascular de indivíduos saudáveis
}

\author{
Elizângela Márcia de Carvalho Abreu ${ }^{[a]}$, Tatiana Sousa Cunha ${ }^{[b]}$, \\ Alderico Rodrigues de Paula Júnior ${ }^{[c]}$, Marco Antonio de Oliveira ${ }^{[\mathrm{d}]}$
}

[a] MSc, professor, Universidade Paulista (Unip), São José dos Campos, SP - Brasil, e-mail: eliz_nasa@yahoo.com.br

[b] PhD, professor, Universidade Federal de São Paulo (Unifesp), São José dos Campos, SP - Brasil, e-mail: cunha@unifesp.br

[c] PhD, professor, Universidade do Vale do Paraíba (Univap), São José dos Campos, SP - Brasil, e-mail: alderico@univap.br

[d] PhD, professor, Universidade do Vale do Paraíba (Univap), São José dos Campos, SP - Brasil, e-mail: oliveirama@univap.br

\begin{abstract}
Objective: To evaluate the effect of Global Postural Reeducation (GPR) on cardiovascular system by heart rate variability (HRV), blood pressure (BP) and heart rate (HR). Materials and methods: Seventeen healthy men $(22.47 \pm 3.02$ years) were submitted to the postures frog on the floor, frog on the air, sitting, standing against the wall and inclined standing, two postures per session. The systolic and diastolic blood pressure (SBP and DBP) and HR were recorded. The intervals between heartbeats were collected during the whole session (Polar S810i). The frequency domain was analyzed (Wavelet Transform), the low frequency (LF) and high frequency (HF) were obtained. The data were analyzed by ANOVA and Tukey ( $<<0.05)$. Results: Increased LF/HF ratio was observed in the frog on the floor $(1 \pm 0.1$ vs. $2 \pm 0.3 \mathrm{p}<0.05)$ and on the air postures $(1 \pm 0.1$ vs. $2 \pm 0.2 \mathrm{p}<0.01)$. There was an increase in SBP in the postures frog on the floor $(123 \pm 2 v s$. $136 \pm 4 \mathrm{p}<0.05)$, frog on the air (122 \pm 2 vs. $133 \pm 3 \mathrm{p}<0.05)$, standing against the wall (123 \pm 2 vs. $136 \pm$ $4 \mathrm{p}<0.05)$, inclined standing (124 \pm 3 vs. $146 \pm 5 \mathrm{p}<0.05)$. There was increase of DBP in the postures frog on the floor ( $69 \pm 2 v s .81 \pm 2 \mathrm{p}<0.01)$, frog on the $\operatorname{air}(72 \pm 2 v s .83 \pm 3 \mathrm{p}<0.05)$, sitting $(85 \pm 2 v s .102 \pm 3$ $\mathrm{p}<0.01)$. There was increase in HR in the postures frog on the air $(67 \pm 2 v s .77 \pm 3 p<0.05)$ and inclined
\end{abstract}


standing ( $88 \pm 3.5 v$ vs. $101 \pm 3 \mathrm{p}<0.05)$. Conclusion: The increase in LF/HF ratio and also the BP and HR indicates high sympathetic activity, possibly related to the work isometric developed during GPR method.

Keywords: Posture. Autonomic nervous system. Cardiovascular system.

\section{Resumo}

Objetivo: Avaliar o efeito da Reeducação Postural Global (RPG) sobre o sistema cardiovascular por meio da variabilidade da frequência cardíaca (VFC), pressão arterial (PA) e frequência cardíaca (FC). Materiais e mé-

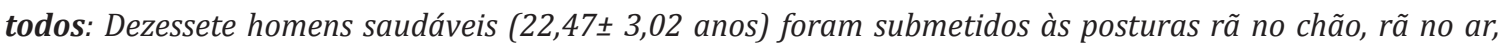
sentada, de pé contra a parede e de pé inclinada, sendo duas posturas por sessão. A pressão arterial sistólica e diastólica (PAS, PAD) e FC foram registradas. Os intervalos entre os batimentos cardíacos foram coletados durante toda a sessão (Polar S810i). O domínio da frequência foi analisado (transformada Wavelet), as bandas de baixa (LF) e a alta frequências (HF) foram obtidas. Os dados foram analisados por ANOVA e Tukey $(p<0,05)$. Resultados: Houve aumento da relação LF/HF nas posturas rã no chão ( $1 \pm 0,1$ vs. $2 \pm 0,3 p<0,05$ ); rã no ar (1 $\pm 0,1$ vs. $2 \pm 0,2 p<0,01)$. Observou-se aumento da PAS nas posturas rã no chão (123 \pm 2 vs. $136 \pm 4 p<0,05)$, rã no ar (122 \pm 2 vs. $133 \pm 3 p<0,05)$, de pé na parede (123 \pm 2 vs. $136 \pm 4 p<0,05)$, de pé inclinada $(124 \pm 3$ vs. $146 \pm 5 p<0,05$ ). Houve aumento da PAD nas posturas rã no chão ( $69 \pm 2$ vs. $81 \pm 2 p<0,01$ ), rã no ar (72 \pm 2 vs. $83 \pm 3 p<0,05$ ), sentada ( $85 \pm 2$ vs. $102 \pm 3 p<0,01$ ). Houve aumento da FC nas posturas rã no ar (67 \pm 2 vs. $77 \pm 3 p<0,05$ ) e de pé inclinada ( $88 \pm 3,5$ vs. $101 \pm 3 p<0,05$ ). Conclusão: $O$ aumento da relação LF/ HF e também da PA e da FC aponta para maior atividade simpática, possivelmente relacionada ao trabalho isométrico desenvolvido durante a realização do método de $R P G$.

Palavras-chave: Postura. Sistema nervoso autônomo. Sistema cardiovascular.

\section{Introduction}

Different studies have shown that external stimulus can affect Heart Rate (HR), an important physiological feature in subject's homeostasis. This occurs not only in simple activity such as postural changes but mainly during intense physical effort such as physical exercise (1).

Temporal and spectral analyses of heart rate variability (HRV) are excellent markers for autonomic cardiac function. These analyses can be done with minimal expense, with a commercial HR monitor easily used in the field and sporting events (2).

The cardiovascular autonomic control is the main method for physiological adjustments because it responds to different situation such as stress, physical exercise and postural changes in normal and pathological conditions (3). At present, HRV is use to predict the mortality risk in different clinical conditions for example in diabetic neuropathology, myocardial infarction and surgery (4).

In addition, $\mathrm{HRV}$ has been used to estimate sympathetic and parasympathetic heart tone during manual therapeutic procedures that include manipulation of the thoracic (5) and cervical vertebrae, where an increase in low frequency (LF) and high frequency (HF) ratio was observed (6). Cervical articular mobilization predominantly caused parasympathetic activity before and during therapeutic procedures, with a raise in the sympathetic activity after the procedure (7). During osteopathic manipulation, a vagal response overcame sympathetic tone (8). After myofascial trigger-point massage on the shoulder, neck and head, parasympathetic activity increased (9).

In addition to HRV, other parameters such as blood pressure (BP) and HR are used to evaluate cardiovascular responsiveness to different stimulation. Mota et al. (10), who used BP, HR and other parameters to evaluate cardiovascular response to sitting posture of the Global Posture Re-Education (GPR) method, found an increase in both parameters during the posture.

In the clinical practice, GPR has been widely used as a physical therapeutic treatment for postural change, mainly in spine disorders and has shown good results. Nevertheless, a review of literature 
found only limited information about the influence of GPR on the cardiovascular system and a patient's risk involved with this therapy due to the physical strain required during postures.

Studies have analyzed the effect of GPR on posture and flexibility of young adults (11); scoliosis (12); thoracic hyperkyphosis (13); plantar distribution and center of force (14). In the only study that correlated GPR and cardiovascular system, Mota et al. (10) previously mentioned.

The aim of the present study was to evaluate the effect of Global Postural Reeducation (GPR) on cardiovascular system by heart rate variability (HRV), blood pressure (BP) and heart rate (HR).

\section{Methods}

This study is an experimental, uncontrolled prospective study. The study was approved by the Research Ethics Committee of the University of the Paraíba Valley (UNIVAP) under H126/CEP/2008 according to the Helsink declaration and Brazilian National Council for Ethical Research (CONEP 196/96).

\section{Casuisthic}

Twenty subjects were recruited, and three of them were excluded for missing one or more treatment sessions. The sample was constituted of 17 health young adult men of $22.47 \pm 3.02$ years, $1.77 \pm 0.08$ $\mathrm{m}$ tall, body mass of $71.38 \pm 12.58 \mathrm{~kg}$, body mass index of $22.69 \pm 3.37 \mathrm{~kg} / \mathrm{m}^{2}$, systolic blood pressure of $123.71 \pm 9.29 \mathrm{mmHg}$ and diastolic blood pressure of $72.12 \pm 6.84 \mathrm{mmHg}$. Volunteer's physical activity level was determined by the International Physical Activity Questionnaire (IPAQ) version 6 and they were all classified as active.

All the subjects signed a free consent form and they were between 18 and 28 years old. Volunteers with any previously diagnosed cardiovascular pathology or with risk factors such as hypertension, diabetes, or obesity were excluded. In addition, volunteers who used medicines with cardio stimulant or cardio depressor effect and those that missed any GPR session were not considered for the study. Females were excluded due to the influence of menstrual cycle on autonomic tonus regulation (15).
Subjects were oriented not to ingest any kind of alcoholic or caffeine beverage, avoid physical exercise 12 hours before GPR session, sleep as well as possible and not ingest food 2 hours before sessions. These warnings follow the recommendation of França et al. (7), Melo et al. (16), Lucini et al. (17).

\section{GPR sessions}

All subjects were submitted to ten sessions of GPR, twice a week and each posture was maintained for 15 min with 5 minutes (min) of resting between each posture. Two postures were applied for each session, one for the anterior and other for the posterior musculature chain, as described by Abreu et al. (11).

When a subject was performed a posture, verbal and physical commands were used to keep the subject in correct postural alignment, correcting the posture when necessary to avoid postural compensation and to maximize stretching (18). The subject performed constant isometric contractions of the muscles under tension each inhale followed by prolonged exhale with the maximum lowering of ribs and abdominals for muscle contraction to stretch the respiratory muscles. During this time, the therapist helped the subject maintain the axial growth.

\section{Collecting RR-intervals of Heart beats and Blood pressure}

The RR-intervals of the electrocardiograms were obtained with a HR monitor (Polar ${ }^{\circledR}$, S810i) validated by Porto and Junqueira Jr. (2). The sensor was positioned just below pectoral muscle. The RR-intervals were collected for the entire $45 \mathrm{~min}$ session including $5 \mathrm{~min}$ before the first posture, during $15 \mathrm{~min}$ of first posture, for $5 \mathrm{~min}$ after performing the posture, during $5 \mathrm{~min}$ before the second posture, during the $15 \mathrm{~min}$ of the second posture and finally $5 \mathrm{~min}$ after the second posture.

Blood pressure and HR were collected in all postures four times with 5 min intervals between each collect. The data were obtained with an automatic monitor (Techline $\left.{ }^{\circledR}, \mathrm{KD}-575\right)$.

All procedures were performed in a quiet, controlled humidity (50 to 60\%) and temperature (24 to $28^{\circ} \mathrm{C}$ ) room. 


\section{Data analysis}

The data were verified using extreme values and the D'Agostino test for normal distribution for all parameters. ANOVA with Tukey post-hoc test was applied to compare analyzed parameters in different moments of the postures with the significant level of $\mathrm{p}<0.05$. All tests were performed in Bioestat 4.0 software.

Data acquired by the HR monitor (Polar, S810i) were transferred to a computer and processed with Polar Precision Performance Software and exported in txt file format. Using Excel software, the artifacts were manually removed. Then the data were loaded into Matlab ${ }^{\circledR} 6.1$ and analyzed with analisevfc software (19) to calculate the frequency domain parameters in the time intervals from 0 to $300 \mathrm{sec}$ (rest period), 300 to 1200 (first posture period) and 1200 to $1500 \mathrm{sec}$ (recovery period). The same procedure was utilized for the second posture.

Analisevfc software based on wavelet transform to calculate the spectral power of RR-intervals was utilized. For each time interval described above, the following parameters were calculated: (a) the mean of low frequency spectral power (LF, 0.04 to $0.15 \mathrm{~Hz}$ ), which refer to sympathetic action; (b) the mean of high frequency spectral power (HF, 0.15 to $0.4 \mathrm{~Hz}$ ) for parasympathetic action; and (c) LF/HF ratio, which shows sympathetic vagal balance. Difference among rest, posture and recovery periods were analyzed.

Blood pressure (systolic and diastolic) and HR data at $0,5,10$ and $15 \mathrm{~min}$ of posture performance were expressed as mean \pm standard error.

\section{Results}

The ANOVA test showed an increase in LF/HF ratio during the frog posture compared to the rest from $1 \pm 0.3$ to $2 \pm 0.3(p<0.01)$ and during the air posture compared to the rest from $1 \pm 0.1$ to $2 \pm 0.2(\mathrm{p}<0.01)$ and between the rest period and the recovery from 1 \pm 0.1 to $2 \pm 0.2(\mathrm{p}<0.05)$. For the other parameters no significant differences were observed. The HRV values are presented in Figures 1, 2 and 3 by means of box plots of the mean and standard error.

A slow increase in BP was observed over time in all of the postures (Table 1). There was a significant increase in SBP in frog posture on the floor for comparisons of means between 0 and $15 \mathrm{~min}(\mathrm{p}<0.05)$ and between 5 and $15 \mathrm{~min}(\mathrm{p}<0.05)$; hip joint angle between 0 and 15 min $(p<0.05)$; standing against the wall between 0 and $15 \min (\mathrm{p}<0.05), 5$ and 15 min $(p<0.05)$; standing posture tilted between 0 and $15 \min (\mathrm{p}<0.05)$ and between 0 and $10 \min (\mathrm{p}<$ $0.05)$. A significant increase in DBP in frog postures on the floor between 0 and $15 \min (\mathrm{p}<0.01)$; hip joint angle between 0 and $15 \mathrm{~min}(\mathrm{p}<0.05)$; seated between 0 and $5 \min (p<0.05)$ between 0 and 10 $\min (\mathrm{p}<0.01)$ and between 0 and $15 \min (\mathrm{p}<0.01)$.

For HR values, a gradual increase was observed during posture execution (Table 2 ). The only significant differences in HR was in frog in the air posture for the time between 0 and $15 \mathrm{~min}(\mathrm{p}<0.05)$ and in standing against the wall for time between 0 and 15 $\min (\mathrm{p}<0.05)$.

\section{Discussion}

In the present study, the LF/HF ratio increased in frog and in the air posture, which points to greater sympathetic activity than parasympathetic activity, as affirmed by Zaza and Lombard (20). The increased activity in bulb encephalic may be a consequence of isometric contraction in involved muscle chains, which probably kept the BP and HR higher during the posture.

It was verified that systolic and diastolic blood pressure increased considerably during all the posture. During the observed cardiovascular alterations, the adjustment in HR and cardiac output probably interact with fluctuations of vasomotor tone to maintain the blood pressure in a physiologic range.

According to Soares and Nóbrega (21), Fardy et al. (22), Berne and Levy (23), McArdle, Katch and Katch (24) and the arterial baroreflex is the major autonomic mechanism directly involved in this reflex response. $\mathrm{BP}$ increased the arteries which activate baroreceptors causing a decrease in HR. In addition, the vasodilatation in peripheral vascular tree prevents an abnormally high level for BP during exercise. Baroreceptor afferent fibers, which are located in the glossopharyngeal (carotid) and the vagus nerve (aorta) and the mechanoreceptors, which are located in the left ventricle, right atrium and large veins, are both responsible for a sympathetic inhibition from the cardiovascular center and respond to changes in BP. These afferent fibers enter the brainstem and pass through a bundle, connect with interneurons in the reticular formation. These interneurons project to the autonomic preganglionic neurons, adjusting the autonomic nervous system, which leads to the control of HR and BP. 


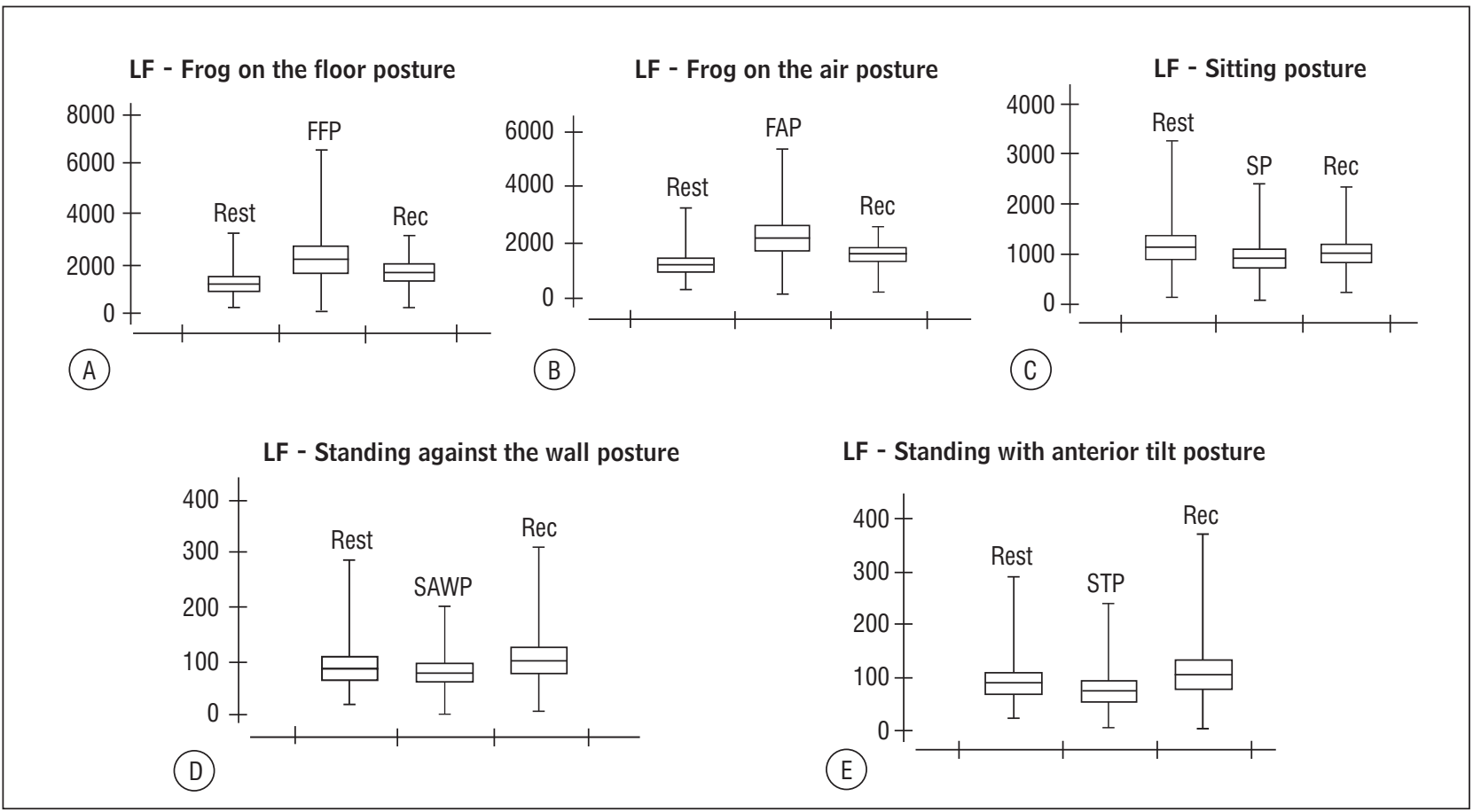

Figure 1 - Boxplot of the mean plus one standard error of the LF values (sympathetic area) during the rest (Rest), the postures: A) frog on the floor (FFP), B) frog in the air (FAP), C) sitting (SP), D) standing against the wall (SAWP), and E) standing with anterior tilt (SATP) and during the recovery (Rec)

Source: Research data.

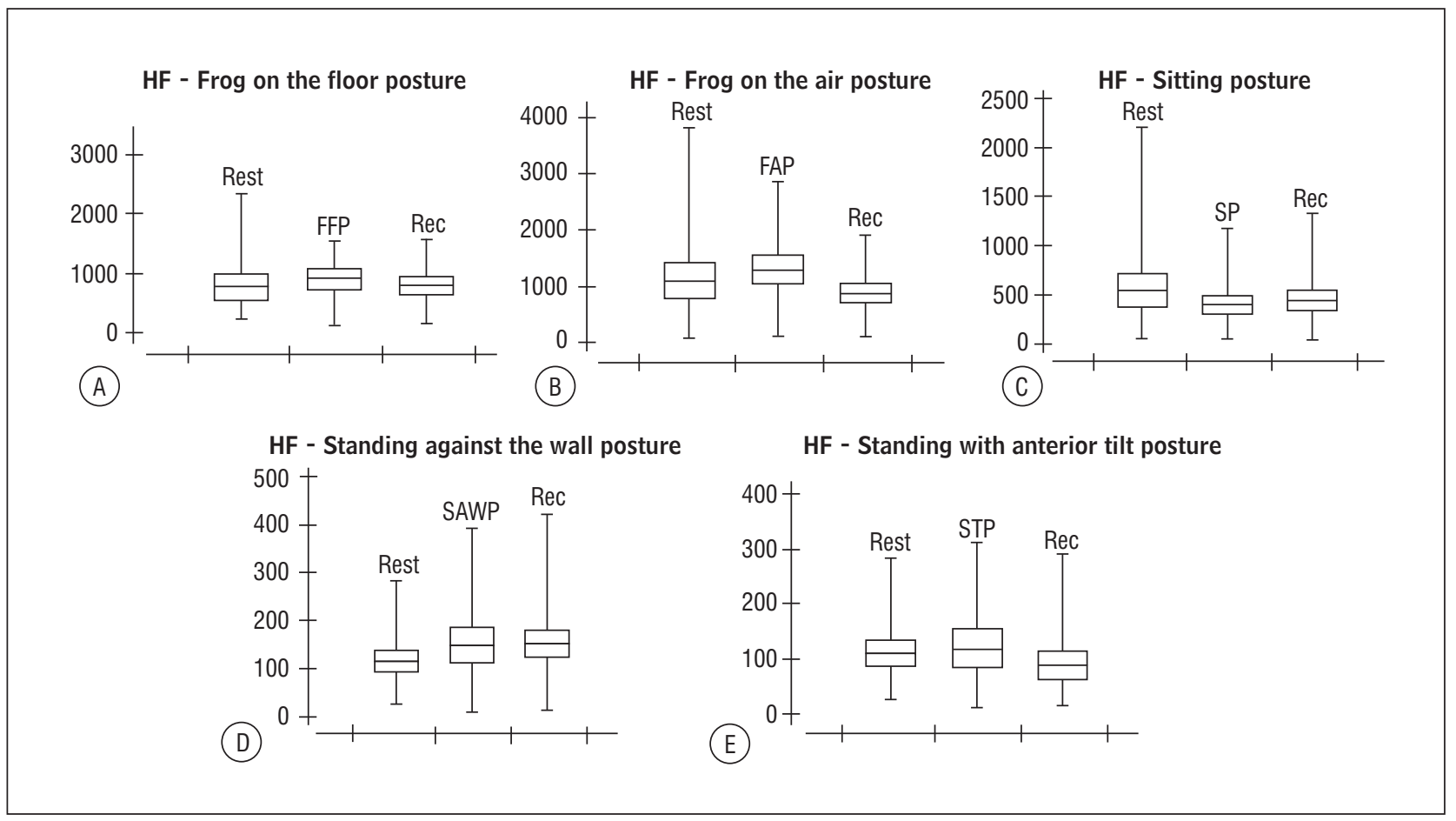

Figure 2 - Boxplot of the mean and standard error of the HF values (parasympathetic area) during the rest, during the postures: A) frog on the floor (FFP), B) frog on the air (FAP), C) sitting (SP), D) standing against the wall (SAWP), and E) standing with anterior tilt (SATP) and the recovery

Source: Research data. 
LF/HF - Frog on the floor posture

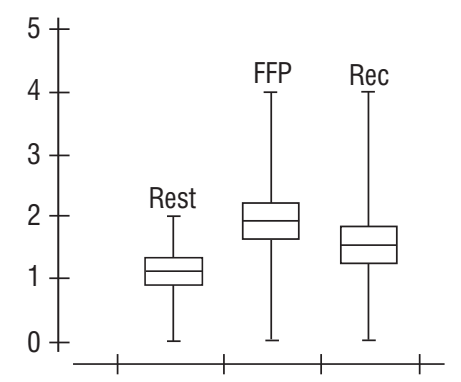

(A)
$\mathrm{LF} / \mathrm{HF}$ - Frog on the air posture

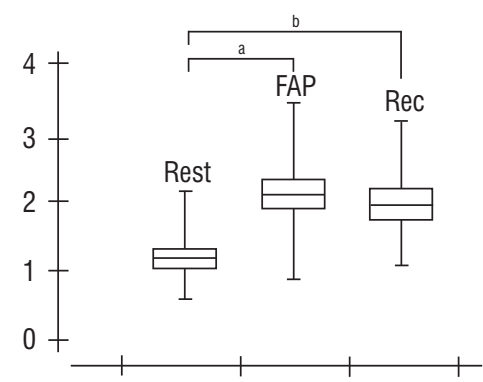

(B)

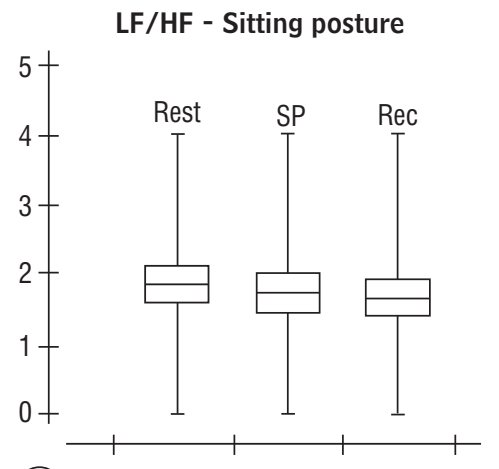

(C)

LF/HF - Standing against the wall posture

LF/HF - Standing with anterior tilt posture

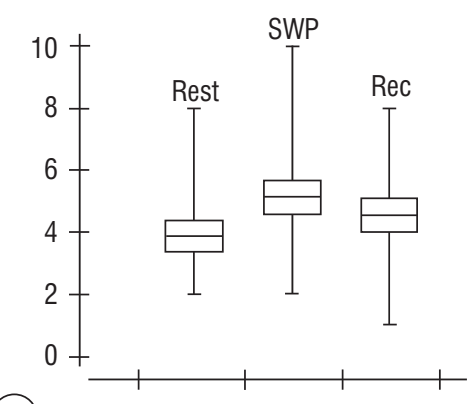

(D)

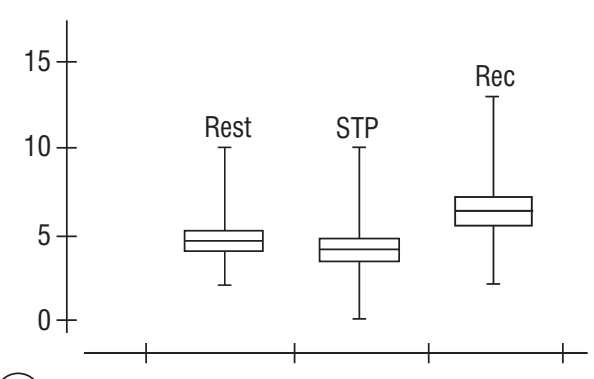

(E)

Figure 3 - Boxplot of the mean and standard error values of LH/HF ratio during the rest (Rest), during the postures: A) frog on the floor (FFP), B) frog on the air (FAP), C) sitting (SP), D) standing against the wall (SAWP), and E) standing with anterior tilt (SATP), and during the recovery

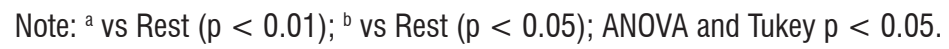

Source: Research data.

Table 1 - Mean and standard error of systolic and diastolic blood pressure at 0, 5, 10 and 15 min during the postures frog on the floor (FFP), frog in the air (FAP), sitting (SP), standing against the wall (SWP) and standing with anterior tilt (STP)

\begin{tabular}{|c|c|c|c|c|c|c|c|c|}
\hline \multirow[t]{2}{*}{ Posture } & \multicolumn{4}{|c|}{ Systolic blood pressure $(\mathrm{mmHg})$} & \multicolumn{4}{|c|}{ Diastolic blood pressure $(\mathrm{mmHg})$} \\
\hline & 0 & 5 & 10 & 15 & 0 & 5 & 10 & 15 \\
\hline FFP & $123 \pm 2.2$ & $122 \pm 3.5$ & $130 \pm 2.6$ & $136 \pm 3.9^{a}$ & $69 \pm 2.0$ & $76 \pm 2.1$ & $76 \pm 2.3$ & $81 \pm 2.4^{d}$ \\
\hline FAP & $122 \pm 1.9$ & $124 \pm 2.6$ & $127 \pm 3.0$ & $133 \pm 3.4^{b}$ & $72 \pm 2.2$ & $73 \pm 1.8$ & $79 \pm 2.7$ & $83 \pm 3.2^{b}$ \\
\hline SP & $132 \pm 3.1$ & $144 \pm 4.3$ & $143 \pm 4.8$ & $145 \pm 4.3$ & $85 \pm 2.1$ & $95 \pm 2.1^{b}$ & $97 \pm 2.8^{e}$ & $102 \pm 2.9^{d}$ \\
\hline SWP & $123 \pm 2.3$ & $122 \pm 2.8$ & $127 \pm 3.4$ & $136 \pm 4.3^{a}$ & $84 \pm 2.5$ & $85 \pm 2.2$ & $89 \pm 2.5$ & $91 \pm 2.4$ \\
\hline STP & $124 \pm 2.9$ & $140 \pm 4.2$ & $142 \pm 4.4$ & $143 \pm 5.0^{\circ}$ & $86 \pm 1.9$ & $93 \pm 2.6$ & $95 \pm 2.7$ & $95 \pm 2.4$ \\
\hline
\end{tabular}

Note: a vs 0 and $5 \min (p<0.05) ;{ }^{b}$ vs $0 \min (p<0.05) ;{ }^{\circ}$ vs 0 and $10 \min (p<0.05) ;{ }^{d}$ vs $0 \min (p<0.01)$; ${ }^{\mathrm{e}}$ vs $5 \min (p<0.01)$; ANOVA and Tukey $p<0.05$.

Source: Research data. 
Table 2 - Mean and standard error of the heart rate at: 0, 5, 10, 15 min during the postures frog on the floor (FFP), frog in the air (FAP), sitting (SP), standing against the wall (SWP) and standing with anterior tilt (STP)

\begin{tabular}{ccccc}
\hline & \multicolumn{4}{c}{ Heart-rate (bpm) } \\
\cline { 2 - 5 } Posture & $\mathbf{0}$ & $\mathbf{5}$ & $\mathbf{1 0}$ & $\mathbf{1 5}$ \\
\hline FFP & $72 \pm 2.8$ & $80 \pm 3.2$ & $82 \pm 3.4$ & $82 \pm 3.4$ \\
FAP & $67 \pm 2.4$ & $70 \pm 2.8$ & $73 \pm 2.5$ & $77 \pm 2.5^{\mathrm{a}}$ \\
SP & $80 \pm 3.2$ & $87 \pm 3.2$ & $92 \pm 3.1$ & $92 \pm 3.6$ \\
SWP & $92 \pm 3.3$ & $102 \pm 3.9$ & $104 \pm 4.0$ & $104 \pm 4.2$ \\
STP & $88 \pm 3.5$ & $97 \pm 3.6$ & $96 \pm 2.6$ & $101 \pm 3.5^{\mathrm{b}}$ \\
\hline
\end{tabular}

Note: av 0 min $(p<0.05)$; ${ }^{\text {b }}$ vs 0 min $(p<0.05)$; ANOVA and Tukey $p<0.05$.

Source: Research data.

Mota et al. (10) studied the effect of sitting posture in healthy young adults on BP and HR and showed results similar to those described by the present study where an increase in sympathetic activity was observed. In Mota et al. the sitting posture was performed in three series with three min of duration instead of continuously for $15 \mathrm{~min}$ as in present study. The time of $15 \mathrm{~min}$ posture is according to the creator of method Souchard (18) and to Castro and Lopes (25).

According to Brum et al. (26) the muscle contraction generates increased energy demand in active muscle and to supply this demand, physiological adjustments in the cardiovascular system are necessary. Spadacini et al. (27) observed a combination of decreased in vagal activity and an enhanced sympathetic activity, even in low intensity exercises.

The results of this study are in agreement with Brum et al. (26), Williams (28) and Gandevia and Hobbs (29) who said that during isometric exercise an increase in HR and peripheral vascular resistance results in a marked increase of blood pressure. These effects are correlated to muscular contractions that promote mechanical obstruction of blood flux in the contracted muscle accumulating metabolites able to activate the chemoreceptor, which enhances sympathetic response in the cardiovascular system. These effects will be directly proportional to intensity, duration and muscular mass involved in the exercise, being greater the larger these factors.

Another important factor that must be emphasized is that many of the LF, HF and LF/HF ratio values did not return to the resting period values, probably because the recovery time was insufficient. This should be verified depth, as the recovery period must be increased so that the values are next to the initial rest.

Further studies should be conducted to better understand the effects of GPR on physiological systems. The results of this study showed an increased cardiovascular work in healthy individuals during the implementation of RPG. Therefore, it is important to develop further studies predicting cardiovascular risk in patients with cardiovascular disease in clinical practice this method has been applied in many patients, such as those with hemiparetic stroke (30). Moreover, it would be interesting to determine whether the practice can improve the RPG or not HRV, and thereby contribute or not to improve the functioning of the cardiovascular system.

\section{Conclusion}

The increase in LF/HF ration and also in BP and HR indicates a predominance of sympathetic activity in relation to parasympathetic possibly associated with isometric activity developed by the muscle chains during the application of the GPR method.

\section{Acknowledgments}

This study was funded by the Coordination for the Improvement of Higher Education Personnel CAPES/PROSUP. We would also like to thank Alene Alder-Rangel for English correction. 


\section{References}

1. Kawaguchi LYA, Nascimento ACP, Lima MS, Frigo L, Paula Jr. AR, Tierra-Criollo CJ, et al. Caracterização da variabilidade da freqüência cardíaca e sensibilidade do barorreflexo em indivíduos sedentários e atletas do sexo masculino. Rev Bras Med Esporte. 2007; 13(4):231-6.

2. Porto LGG, Junqueira Jr. L. Comparação das análises temporal e espectral da variabilidade em curto prazo da frequência cardíaca, baseada no ECG convencional e no frequencímetro Polar ${ }^{\circledR}$. Brasília Med. 2006;43(1-4):78-9.

3. Reis MS, Deus AP, Simões RP, Aniceto IAV, Catai AM, Borghi-Silva A. Controle autonômico da frequência cardíaca de pacientes com doenças cardiorrespiratórias crônicas e indivíduos saudáveis em repouso e durante a manobra de acentuação da arritmia sinusal respiratória. Rev Bras Fisioter. 2010;14(2):106-13.

4. Heart rate variability. Standards of measurement, physiological interpretation, and clinical use. Task Force of the European Society of Cardiology and the North American Society of Pacing and Electrophysiology. Eur Heart J. 1996;17(3):354-81.

5. Budgell B, Polus B. The effects of thoracic manipulation on heart rate variability: a controlled crossover trial. J Manipulative Physiol Ther. 2006;29(8):603-10.

6. Budgell B, Hirano F. Innocuous mechanical stimulation of the neck and alterations in heart-rate variability in healthy young adults. Auton Neurosci. 2001;91(1-2):96-9.

7. França AH, Armond RE, Pain NG, Medeiros WM, Juliano Y. Alterações do sistema nervoso autônomo decorrente da mobilização articular cervical. Fisioter Bras. 2005;6(4):271-6.

8. Henley CE, Ivins D, Mills M, Wen FK, Benjamin BA. Osteopathic manipulative treatment and its relationship to autonomic nervous system activity as demonstrated by heart rate variability: a repeated measures study. Osteopath Med Prim Care. 2008;2:7.

9. Delaney JP, Leong KS, Watkins A, Brodie D. The short-term effects of myofascial trigger point massage therapy on cardiac autonomic tone in healthy subjects. J Adv Nurs. 2002;37(4):364-71.
10. Mota YL, Barreto SL, Bin PR, Simões HG, Campbell CSG. Respostas cardiovasculares durante a postura sentada da Reeducação Postural Global. Rev Bras Fisioter. 2008;12(3):161-8.

11. Abreu EMC, Paula Jr. AR, Oliveira MA. Avaliação da postura e da flexibilidade em adultos jovens antes e após tratamento através do método de Reeducação Postural Global. Fisioter Bras. 2010;11(3):210-5.

12. Fregonesi CEPT, Valsechi CM, Masselli MR, Faria CRS, Ferreira DMA. Um ano de evolução da escoliose com RPG. Fisioter Bras. 2007;8(2):140-2.

13. Pita MC. Cifose torácica tratada com Reeducação Postural Global. Arq Ciênc Unipar. 2000;4(2):159-64.

14. Teodori RMI, Guirro ECO, Santos RM. Distribuição da pressão plantar e localização do centro de força após intervenção pelo método de Reeducação Postural Global: um estudo de caso. Fisioter Mov. 2005; 18(1):27-35.

15. Yildirir A, Kabakci G, Akgul E, Tokgozoglu L, Oto A. Effects of menstrual cycle on cardiac autonomic innervation as assessed by heart rate variability. Ann Noninvasive Electrocardiol. 2002;7(1):60-3.

16. Melo RC, Santos B, Silva E, Quitério RJ, Moreno MA, Reis MS, et al. Effects of age and physical activity on the autonomic control of heart rate in healthy men. Braz J Med Biol Res. 2005;38(9):1331-8.

17. Lucini D, Covacci G, Milani R, Mela GS, Malliani A, Pagani MA. Controlled study of the effects of mental relaxation on autonomic excitatory responses in healthy subjects. Psychosom Med. 1997;59(5):541-52.

18. Souchard PE. Reeducação Postural Global: método do campo fechado. 3 ed. São Paulo: Ícone; 1998.

19. Nascimento ACP. Técnicas de análise da variabilidade da frequência cardíaca no domínio da frequência e análise no domínio do tempo (dissertação). São José dos Campos: Universidade do Vale do Paraíba; 2007.

20. Zaza A, Lombardi F. Autonomic indexes based on the analysis of heart rate variability: a view from the sinus node. Cardiovasc Res. 2001;50(3):434-42.

21. Soares PPS, Nóbrega ACL. Variabilidade da pressão arterial e exercício físico. Rev Bras Hipertens. 2005; 12(1):33-5. 
22. Fardy PS, Franklin BA, Porcari J, Verrill ED. Técnicas de treinamento em reabilitação cardíaca. São Paulo: Manole; 2001.

23. Berne RM, Levy MN. Fisiologia. 4. ed. Rio de Janeiro: Guanabara Koogan; 2000.

24. McArdle WD, Katch F, Katch VL. Fisiologia do exercício: energia, nutrição e desempenho humano. 4. ed. Rio de Janeiro: Guanabara Koogan; 1996.

25. 25. Castro PCG, Lopes JAF. Avaliação computadorizada por fotografia digital, como recurso de avaliação na Reeducação Postural Global. Acta Fisiatr. 2003; 10(2):83-8.

26. Brum PCB, Forjaz CLM, Tinucci T, Negrão CN. Adaptações agudas e crônicas do exercício físico no sistema cardiovascular. Rev Paul Educ Fís. 2004;18(N. esp.):21-31.

27. Spadacini G, Passino C, Leuzzi S, Valle F, Piepoli M. Frequency-dependent baroreflex control of blood pressure and heart rate during physical exercise. Int J Cardiol. 2006;107(2):171-9.
28. Williams CA. Effect of muscle mass on the pressor response in man during isometric contractions. J Physiol. 1991;435:573-84.

29. Gandevia SC, Hobbs SF. Cardiovascular responses to exercise in man: central and reflexes contribuitions. J Physiol. 1990;430:105-17.

30. Gomes BM, Nardoni GCG, Lopes PG, Godoy E. O efeito da técnica de Reeducação Postural Global em um paciente com hemiparesia após acidente vascular encefálico. Acta Fisiatr. 2006;13(2):103-8.

Received: 01/20/2013

Recebido: 20/01/2013

Approved: 09/30/2013

Aprovado: 30/09/2013 